DOI: $10.19195 / 2082-8322.8 .1$

Igor Borkowski

Uniwersytet Wrocławski

\title{
Kodować, planować, komunikować
}

Bezokolicznik nie jest poręczną stylistycznie i komunikacyjnie formą. Postanowiłem jednak wpisać aż trzy bezokoliczniki do tytułu wprowadzenia do 8. numeru czasopisma „Dziennikarstwo i Media”, by pokazać specyficzne wyzwania, jakie stoją przed tymi, którzy konceptualizują proces komunikacji, którzy strategicznie go projektują, wreszcie przed tymi, którzy nadają i odbierają przekazy medialne.

W niniejszym numerze znajdą Państwo teksty z dwóch nurtów tematycznych. Pierwszy dotyczy kodów w komunikacji, drugi - strategii komunikowania. Wydaje się, że oba kręgi zainteresowań autorów są komplementarne, dopełniają się, pozwalają na wysnucie na wyższym poziomie ogólności pewnych dopełniających się wniosków.

W prezentowanych tu artykułach zarysowuje się ciekawa perspektywa, którą wprowadzają młodzi i najmłodsi badacze. Bardzo się cieszę, że ponownie na łamach czasopisma pojawiają się - i to licznie - debiutanci. Postanowiłem nagradzać szansą na publikację tekstu w czasopiśmie tych, których prace dyplomowe merytorycznie osiągają najwyższy poziom. Jest to zatem i praca zorientowana na kształtowanie warsztatu badawczego, i docenienie zalet młodych badaczy, ich świeżego spojrzenia, a także jakiegoś ulotnego zapewne zafascynowania tym, co dla badań najważniejsze: pierwszą miłością. Widać ją w wielu miejscach. Przejawia się w determinacji badawczej, w poszukiwaniu nowych dróg, w braniu na barki takich wyzwań, których wielu starszych i bardziej doświadczonych badaczy już się nie podejmie. Niczym sterany himalaista spojrzą, wzruszą ramionami. „Tędy nie da się pójść. Tym podejściem nie ma sensu" - powiedzą. Ale pojawiają się młodzi, nowi. Oni idą. Tym razem to aż troje autorów tekstów, które powstały na bazie prac dyplomowych: Kacper Kosma Kocur, Jakub Łączniak i Joanna Paszek. Gratulując debiutu, życzę dalszych sukcesów. Owoce ich zmagań mogą Państwo znaleźć na stronach tego numeru „Dziennikarstwa i Mediów". 
Ambicją czasopisma i jego autorów jest, aby łączyć perspektywę bieżącą z szerszym spojrzeniem na sprawy komunikacji medialnej, społecznej, dziennikarstwa, komunikowania wizerunkowego. Co zatem jeszcze można znaleźć w tym numerze?

Blok tekstów skoncentrowanych wokół problematyki kodów w komunikacji otwiera rozprawa-esej Jerzego Olka, dotycząca szeroko pojętej problematyki artefaktów obrazowych w komunikacji. Kolejne teksty są już skoncentrowane na zagadnieniach szczegółowych: komunikacji międzypokoleniowej, problematyce marketingu politycznego i wizerunku polityków w kontekście komunikowanych wartości, emocji w komunikacji oraz doświadczeniach aktywności szczególnej grupy respondentów w social mediach.

Część druga to propozycja zobaczenia komunikacji od strony przyjmowanych i realizowanych, a przez badaczy rekonstruowanych strategii komunikacyjnych. W tym bloku znajdziecie Państwo prace odnoszące się do warsztatu dziennikarskiego i badań o charakterze systemowym, projektowania komunikacji, komunikatów reklamowych i sposobów ich analizowania oraz medialnych obrazów świata.

Prezentowane w 8 . numerze czasopisma teksty odzwierciedlają profile naukowe i obszary zainteresowań pracowników, doktorantów i współpracowników Instytutu Dziennikarstwa i Komunikacji Społecznej Uniwersytetu Wrocławskiego oraz badaczy z innych ośrodków.

Trudno w tym momencie dziejów komunikacji społecznej uniknąć odniesień do tytułowych komponentów działań nadawczych: „kodować”, „planować”, „komunikować”. Brzmią one bowiem dwuznacznie - wskazują na wpisaną w działania komunikacyjne socjotechnikę, nieuchronność cynicznej gry, w której wszystkie dostępne dane ma nadawca, a odbiorca może co najwyżej próbować uświadomić sobie, że tak właśnie jest, i po omacku szukać drogi wyjścia. Wydaje się, że jest to w jakiejś mierze konstatacja poprawna, choć nie wyczerpuje w pełni tego, co dziś w mediach, w dziennikarstwie, w komunikacji społecznej jest ważne. Wciąż bowiem żywa jest refleksja nad mediami jakościowymi, wciąż garną się na rzetelnie prowadzone studia dziennikarskie liczne grupy kandydatów, dla których nie jest obojętne to, co kto i na jakim merytorycznie poziomie podaje w mediach do konsumowania odbiorcom. Przesłanek do zachowania optymizmu dostarczają także sami odbiorcy mediów. Znajdziemy je wbrew wszechogarniającemu potocznemu mniemaniu, że sieć i przestrzeń otwartej agory dyskusji to wyłącznie domena hejtu i agresywnego emocjonalnego odreagowania własnych niekompetencji. Gdy czytamy uwagi spokojne, apelujące o rozwagę, dyskusję na argumenty, gdy pod fejkowym newsem znajdujemy spontaniczną reakcję internautów, którzy prostują to, co dla jednych nawet prostowania nie wymaga, bo jest po prostu irracjonalne, lecz dla drugich może być ratunkiem przed dezinformacją, to mamy przesłanki, by wierzyć w komunikacyjny i informacyjny instynkt samozachowawczy. Wciąż trzyma się reportaż, wciąż jakość ma znaczenie i nie tylko sama się ceni, ale jest doceniana przez odbiorców.

Warte podjęcia byłyby badania nad tym, czy właśnie to nie po stronie odbiorców jest dziś większe zapotrzebowanie na sprawdzone i jakościowe produkty medialne, 
może to odbiorcy, a nie nadawcy są dzisiaj tymi, którzy chcieliby lepiej? Może mediom, PR-owcom, rzecznikom prasowym, brandingowcom, spin doktorom i samym medioznawcom jest wygodniej myśleć, że skoro odbiorca wszystko kupi, to już nie trzeba utrzymywać standardu? Koniecznie trzeba się nad tym poważnie zastanowić! 